\title{
Contribution of Micro-Finance on Socio-Economic Development of Rural Community
}

\section{Chandra Prasad Dhakal ${ }^{1} \&$ Prof. Dr. Govinda Nepal ${ }^{2}$}

\author{
${ }^{1} \mathrm{PhD}$ Scholar, Mewar University, Rajasthan, India \\ ${ }^{2}$ Professor of Economics, Tribhuvan University, Kathmandu, Nepal

\section{Corresponding Author}

Chandra Prasad Dhakal

Email: chandradhakal@hotmail.com

\begin{abstract}
Microfinance institutions are established to promote the financial activities mainly saving and credit in community. Microfinance's activities are focused on reducing poverty level of community people. Poor, disadvantaged, marginalize and women are in mainstream of microfinance's programs. The study was focused on finding out the contribution of microfinance on socio-economic development of rural community. The study was based on the quantitative design. Cross-sectional data was collected from the 8 microfinances of Syangja district. Purposive sampling technique was adopted to select the respondents. The perceptual analysis of data reported the significant contribution of micro-finance in social change and development. Microfinances working since 2 to 20 years covering the diverse field of social activities were the samples of the study. There was a need to improve the internal management of microfinance to provide the services more effectively.
\end{abstract}

\section{KEYWORDS}

Contribution, Microfinance, Rural community, Socio-economic development

\section{INTRODUCTION}

Microfinance is defined as a development tool that grants or provides financial services and products such as very small loans, savings, micro-leasing, micro-insurance and money transfer to assist the very or exceptionally poor in expanding or establishing their businesses. It is mostly used in developing economies where SMEs do not have access to other sources of 
financial assistance (Robinson, 2003). The informal financial institutions constitute; village banks, cooperative credit unions, state owned banks, and social venture capital funds to help the poor. These institutions are those that provide savings and credit services for small and medium size enterprises. They mobilize rural savings and have simple and straight forward procedures that originate from local cultures and are easily understood by the population(Germinis, 1991). The development of microfinance programs gained a worldwide acceptance and popularity since 1980s in providing financial services to the poor. It is one way of the antipoverty instrument of the development programs. Numerous institutions in many parts of the developing world have been providing micro-credit and recovering their loans. The Grameen Bank's group lending methodology became widely adopted by institutions in many parts of the world (Robinson, 2003). Relative to the experience of other developing countries, microfinance development in its institutionalized form is a recent phenomenon in Nepal.

Where there is no formal banking system in any rural area, microfinance is a way to help alleviate poverty in rural communities. Different studies fluctuate on the number of poverty stricken people in the world, but some studies say that around 300 million to 360 million are in "absolute poverty" (Premchander, 2009, p. 1). Furthermore, research has shown that over 2 billion people do not have access to formal credit institutions (Hudon, 2009, p. 17). Access to monetary resources helps people create profits and lessen poverty around the globe. Since microfinance is a system that distributes small loans to poor people in order for them to generate income and start their own small businesses, it has the capability to lessen poverty as well as promote entrepreneurship, social and economic development in poor communities (Lazar \& P., 2008, p. 34).

Poor households are stuck in the vicious cycle of poverty; their resources are locked up in inefficiency, including their best resource which is their "labour". There are a couple of reasons and one of them is financial liquidity constraints. For example, these poor peasants might have more family members willing to help in agricultural farming. But if they cannot afford improved crop varieties and better farm inputs, therefore, becomes inefficient and unproductive (Taiwo, June, 2012). Many governments and donor agencies regard that lack of financial services as one of the most important factor hindering poor households from efficient and successful production. Agricultural finance has the unique features of supporting a large 
number of rural populations in developing countries and to reduce poverty. On the one hand, it provides people the possibility to gain livelihood, and on the other hand it provides the people with opportunities to live with self-respect (Coady, Grosh, \& Hoddinott). It is the responsibility of the state to provide adequate policy framework for proficient and cost efficient mechanism for rural finance market to support agricultural and rural development (Barrett \& Clay, 2003, p. 177). A majority of peasants in developing countries have no access to any banking system or microcredit (Schady, 2002).Microcredit has the potential to play a role in increasing access to financial services and proximity between clients and cooperatives (Roodman \& Morduch, 2009).

Financial services to poor people, particularly from rural areas may help farmers to access new technologies and high yield varieties for agriculture production. Provision of financial services and products has trickle-down effects on the poor's livelihood. Microfinance for agriculture has the potential to address all factors which are linked to poverty reduction e.g. improved health, better education, better agricultural practices and employment opportunities (Komives, Halpern, Foster, \& Wodon, 2005). Rural microfinance products in many parts of the world are already launching innovative products especially designed to rural needs and poverty reduction.

\section{METHOD}

The study was based on the descriptive research design and purposively microfinances were selected from the study areas. Total 8 microfinances were selected for the data collection. Structured question was designed in Five point Liket's scale. Branch manager, Executive officer and Program Managers were selected for the in-depth interview to know from them their experiences on contribution of microfinance in socio-economic development of rural community. Frequency table was used to analyse the data.

\section{RESULT \& DISCUSSION}

The study covered 8 Micro finance institutions of Syangja district of Nepal. In average the institutions were working from 2 to 20 years (mean 12.3750). They covered 5-58 VDCs for the micro finance activities. As the data given by the institutions, they were providing services to around 12,000 household. The data showed that minimum 50\% to maximum $92 \%$ members of 
microfinance applied for loan for the purpose of farming, petty trade, small scale manufacturing and Artisan.

The data presented in the table below collected the opinion of manager of micro finance to explore the contribution of micro finance in socio-economic status of beneficiaries. In total, $25 \%$ agreed followed by $75 \%$ strongly agreed regarding the contribution of micro finance to uplift the income status of beneficiaries. This result is supported by Taiwo's research "Analysis of loan received by the respondents from MFIs shows that about $64 \%$ of them have benefitted from one form of loan or the other from their respective microfinance banks " (June, 2012, p. 134). Similarly, micro finance agreed that community people had used the loan money for the same purpose for which they were given by micro finance. In total 100\% micro finance agreed that microfinance could be effective means to reduce poverty. "Microfinance institutions can really get people out of the poverty with consistent utilization of loans for developmental activities by their customers. This also impacts greatly on Customers' saving habit and income generation. By financing more small and medium scale enterprises, the MFI have made a significant contribution to creation of employment and improving household income" (Taiwo, June, 2012, p. 156).Micro finance institutions should be established in the rural areas so that it can provide the saving and credit service to the needy people. The statement was strongly agreed by the micro finance itself.

$100 \%$ microfinance disagreed on the charging of the same interest rates by microfinance as the mainstream banks were charging because as their experiences, microfinance had to charge more interest rate in loan than the other bank. It was also interesting that low income group people were also paying the loan on time which helped build the trust of microfinance on their customers of different income group. In total $87.5 \%$ microfinance were not ready to provide loan for the household level expenditure, e.g. food, children education, minor house repairs, farming, fishing, health matters and other emergencies. Microfinance was interested to finance only in those sectors where from farmers could earn; only in productive sectors so they discouraged the use of loan money for daily expenditure. It was also one good practice to reduce the unnecessary burden of loan for farmers. Around $88 \%$ microfinance said that Nepal Government had given good support to microfinance for their program implementation. But $100 \%$ microfinances disagreed on 10 million Nepalese rupees being sufficient to run the microfinance. 
ISSN: 2362-1303 (Paper) | elSSN: 2362-1311(Online)

Microfinances were mainly focused on uplifting the socio-economic status of women. Women are bound within the household activities and don't get enough opportunity to go outside of home and involve in other activities. If women should be educated or empowered then she can support or empower her family members; she can well manage the health and education of the children. On the other hand, male migration is also increasing in Nepal, in such condition female has to take overall responsibilities of management of house and children. The Microfinance program provides the skill based training so that they can earn by based on her skills.

\begin{tabular}{|c|c|c|c|c|c|c|c|}
\hline $\mathrm{SD}=$ Strongly disagree, $\mathrm{D}=$ disagree, $\mathrm{N}$ & $=\mathrm{N}$ & itr: & $\mathrm{A}=\mathrm{Ag}$ & $\mathrm{e}, \mathrm{S}$ & Stro & $\overline{\mathrm{y} A \xi}$ & \\
\hline Statements & & SD & $\mathbf{D}$ & $\mathbf{N}$ & $\mathbf{A}$ & $\mathbf{S A}$ & Total \\
\hline Microfinance has improved the lot of & $\mathrm{N}$ & & & & 2 & 6 & 8 \\
\hline the low-income group in service area & $\%$ & & & & 25.0 & 75.0 & 100.0 \\
\hline Funds disbursed are applied for the & $\mathrm{N}$ & & & & 6 & 2 & 8 \\
\hline purpose for which they were given & $\%$ & & & & 75.0 & 25.0 & 100.0 \\
\hline Microfinance is really the answer to & $\mathrm{N}$ & & & & 1 & 7 & 8 \\
\hline $\begin{array}{l}\text { poverty alleviation if properly } \\
\text { practiced }\end{array}$ & $\%$ & & & & 12.5 & 87.5 & 100.0 \\
\hline More microfinances should be & $\mathrm{N}$ & & & 1 & 1 & 6 & 8 \\
\hline $\begin{array}{l}\text { established, particularly in the rural } \\
\text { areas of the country }\end{array}$ & $\%$ & & & 12.5 & 12.5 & 75.0 & 100.0 \\
\hline Microfinances charge same interest & $\mathrm{N}$ & & 8 & & & & \\
\hline rates as the mainstream banks & $\%$ & & 100.0 & & & & \\
\hline Microfinances charge higher interest & $\mathrm{N}$ & & & & 6 & 2 & 8 \\
\hline rate than the mainstream bank & $\%$ & & & & 75.0 & 25.0 & 100.0 \\
\hline Low-income group repay loans & $\mathrm{N}$ & & & & 7 & 1 & 8 \\
\hline $\begin{array}{l}\text { extended to them by microfinance } \mathrm{s} \\
\text { satisfactorily }\end{array}$ & $\%$ & & & & 87.5 & 12.5 & 100.0 \\
\hline Households use loans be given to them & $\mathrm{N}$ & & 7 & & 1 & & 8 \\
\hline $\begin{array}{l}\text { for food, children education, minor } \\
\text { house repairs, farming, fishing, health } \\
\text { matters and other emergencies }\end{array}$ & $\%$ & & 87.5 & & 12.5 & & 100.0 \\
\hline
\end{tabular}




\begin{tabular}{|c|c|c|c|c|c|c|}
\hline \multirow{2}{*}{$\begin{array}{l}\text { The Government has done enough to } \\
\text { support microfinance sector in Nepal }\end{array}$} & $\mathrm{N}$ & 1 & & 7 & & 8 \\
\hline & $\%$ & 12.5 & & 87.5 & & 100.0 \\
\hline \multirow{2}{*}{ Main customers are women } & $\mathrm{N}$ & & 1 & 1 & 6 & 8 \\
\hline & $\%$ & & 12.5 & 12.5 & 75.0 & 100.0 \\
\hline \multirow{2}{*}{$\begin{array}{l}\text { Bank provides services in the areas of } \\
\text { money transfer, savings etc }\end{array}$} & $\mathrm{N}$ & 5 & & 2 & 1 & 8 \\
\hline & $\%$ & 62.5 & & 25.0 & 12.5 & 100.0 \\
\hline \multirow{2}{*}{$\begin{array}{l}\text { Total Rs. } 10 \text { million capital base is } \\
\text { adequate for the operations of } \\
\text { microfinance }\end{array}$} & $\mathrm{N}$ & 8 & & & & 8 \\
\hline & $\%$ & 100.0 & & & & 100.0 \\
\hline \multirow{2}{*}{$\begin{array}{l}\text { Many microfinance are fail as a result } \\
\text { of fraud and insider abuse }\end{array}$} & $\mathrm{N}$ & 7 & & 1 & & 8 \\
\hline & $\%$ & 87.5 & & 12.5 & & 100.0 \\
\hline \multirow{2}{*}{$\begin{array}{l}\text { Easy to facilitate loan packaging to } \\
\text { Group membership }\end{array}$} & $\mathrm{N}$ & & & 2 & 6 & 8 \\
\hline & $\%$ & & & 25.0 & 75.0 & 100.0 \\
\hline \multirow{2}{*}{$\begin{array}{l}\text { Microfinance can really promote } \\
\text { business development and bring about } \\
\text { economic development }\end{array}$} & $\mathrm{N}$ & & & 5 & 3 & 8 \\
\hline & $\%$ & & & 62.5 & 37.5 & 100.0 \\
\hline
\end{tabular}

Microfinances are involved in the different social development activities also than the only saving and credit because microfinances have committed to reduce the level of poverty in the society. Economic and social uplifting is strongly associated with each other so it should be launched together. From the study it was reported that $87.5 \%$ microfinance failed and could not achieve the goal because of the fraud and insider wrong activities. So it was also recommended to formulate the very effective management team who could work transparently, visibly and are result oriented. Microfinance institutions are providing the banking services for the communities that do not have easy access to the mainstream banks and they are providing the economic and social services to change the social status of people so it should be unpolitical, free from the corruption and more transparent. $100 \%$ microfinances agreed that microfinances helped promote the businesses and brought the changes in economy. This result is supported by Okibo and Makanga's research that states, "Majority of the client respondents $86.9 \%$ reported that their living standards had improved (2014, p. 91)". 


\section{CONCLUSION}

Microfinance institutions are developed with the common purpose of contributing in the socioeconomic changes of community. Microfinances were not working in the field of saving and credit but also providing the skill based income generating activities to uplift the economic status of people. The importance of microfinance was felt more in rural areas than the urban areas because of the less infrastructural development in in the former. Microfinances' activities are more effective to reduce the poverty level. It has promoted the saving and credit habit of people. Microfinance has promoted the business activities by providing the load facilities. Microfinance institutions accepted that they charged higher interest rates than the other banking institutions because of its own sustainability strategy. It was necessary to monitor the microfinance activities from the government to strengthen the capacity of management and promote the effectiveness of communities' services.

\section{REFERENCES}

Barrett, C., \& Clay, D. C. (2003). How Accurate Is Food-For-Work Self-Targeting in the Presence of Imperfect Factor Markets? Evidence from Ethiopia. Journal of Development Studies, 39(5), 152-180.

Coady, D., Grosh, M., \& Hoddinott, J. (n.d.). Targeted Anti-Poverty Interventions: A Selected Annotated Bibliography. International Food Policy Research Institute Mimeo.

Germinis, D. (1991). Financial systems and development: What role for the formal and informal sector? Paris: OECD development centre.

Hudon, M. (2009). Should Access to Credit be a Right? Journal of Business Ethics, 84, 17-28.

Komives, K., Halpern, J., Foster, V., \& Wodon, Q. (2005). Water, Electricity and the Por: Who Benefits from Utility Subsidies. World Bank.

Lazar, D., \& P., P. (2008). Micro finance and poverty eradication: Indianand global experiences. New Delhi: Pondicherry University; New Century Publications, Pondicherry.

Okibo, B. W., \& Makanga, N. (2014). Effects of micro finance institutions on poverty reduction in Kenya. International Journal of Current Research and Academic Review, 2(2), 7695. 
ISSN: 2362-1303 (Paper) | elSSN: 2362-1311(Online)

Premchander, S. (2009). Multiple meanings of money: how women see microfinance. Los Angeles: SAGE Publications.

Robinson, M. (2003). The microfinance revolution: Sustainable finance for the poor. Wasington D.C.: World Bank.

Roodman, D., \& Morduch, J. (2009). The Impact of Microcredit on the Poor in Bangladesh: Revisiting the Evidence. Center for Global Development.

Schady, N. (2002). Picking the Por: Indicatrs for Gegraphic Targetin in Peru. Review of Incme and Wealth Series, 48(3), 417-433.

Simler, I., \& Nhate, V. (2005). Poverty, Inequality and Geograpic Targeting: Evidence from Small Area Estinates in Mozambique.

Skoufias, E., \& Coady, D. (2007). Are the welfare losses from imperfect targeting important. Economica, 74, 756-776.

Taiwo, J. (June, 2012). The Impact Of Microfinance On Welfare And Poverty Alleviation In Southwest Nigeria. 